\title{
MODAL SOSIAL DALAM PEMBERDAYAAN MASYARAKAT PETANI MARKISA DI SUMATERA UTARA
}

\author{
Kustoro Budiarta ${ }^{1)}$, Ahmad Hidayat ${ }^{1)}$, Sienny ${ }^{1)}$ Riza Indriani ${ }^{1)}$ \\ ${ }^{1)}$ Fakultas Ekonomi Universitas Negeri Medan \\ *Penulis korespondensi: kustorobudiarta@unimed.ac.id
}

\begin{abstract}
Analisis situasi awal menunjukkan bahwa pemberdayaan masyarakat melalui kelompok petani markisa dalam membangun pola kemitraan menjadi satu kebutuhan yang urgen terutama melihat permasalahan yang dihadapi oleh petani markisa di Propinsi Sumatera Utara. Selain itu, oleh karena modal sosial dinilai sangat berperan secara ekonomi untuk meningkatkan produktivitas usaha dan efisiensi, maka penelitian ini dilakukan dengan tujuan untuk mengetahui pengaruh modal sosial yang idukur dengan kepercayaan, norma sosial dan jaringan kerja terhadap perilaku petani markisa di Propinsi Sumatera Utara. Subyek penelitian ini adalah petani markisa, dengan teknik purposive sampling maka ditentukan empat kabupaten yaitu Kabupaten Karo, Kabupaten Simalungan, Kabupaten Dairi dan Kabupaten Tapanuli Utara. Pengambilan sampel petani markisa digunakan stratified random sampling dengan memperhatikan responden yang benar-benar dapat memberikan informasi data yang tepat sesuai dengan tujuan penelitian. Jumlah sampel penelitian sebanyak 100 responden. Modal sosial diukur dengan variabel kepercayaan, norma sosial dan jaringan kerja sebagai variabel independen dan pemberdayaan masyarakat diukur dengan perilaku petani sebagai variabel dependen. Data dikumpulkan menggunakan kuesioner dengan Alpha sebesar 0,917 untuk perilaku petani, 0,916 untuk kepercayaan, 0,877 untuk norma sosial dan 0,793 untuk jaringan kerja. Pengumpulan data juga dilakukan melalui wawancara mendalam. Data yang telah dikumpulkan selanjutnya dianalisis menggunakan statistik deskriptif dan inferensial, sedangkan uji hipotesis menggunakan uji $\mathrm{F}$ untuk mengetahui pengaruh simultan dan uji hipotesis secara parsial digunakan statistik uji t. Hasil penelitian menunjukkan bahwa baik secara simultan maupun secara parsial kepercayaan, norma sosial dan jaringan kerja berpengaruh signifikan terhadap perilaku petani..
\end{abstract}

Keywords : modal sosial, kepercayaan, norma sosial, jaringan kerja, perilaku petani 


\section{PENDAHULUAN}

Pengembangan bisnis markisa dalam bentuk produksi buah markisa dan produk olahan serta pemasaran markisa di Sumatera Utara banyak mengalami kendala. Walaupun komoditas ini telah lama dirintis untuk diusahakan sebagai komoditas buahbuahan yang menjadi unggulan tetapi beberapa tahun terakhir terjadi penurunan pada komoditas ini. Perkembangan produksi buah markisa di Kabupaten Karo selama 5 tahun terakhir mengalami penurunan yang cukup tajam. Pada tahun 2014 jumlah hasil produksi markisa sebanyak 7.938 ton, dan pada tahun 2018 sebanyak $1.751,9$ ton sedangkan produksi pada tahun 2019 sebanyak 2.581 ton. Sebenarnya hasil pengamatan di lapangan menunjukkan bahwa pemasaran produk olahan buah markisa masih mempunyai peluang untuk dikembangkan terutama dalam hal peningkatan volume pemasaran.

Namun pengembangan produksi (buah markisa dan produk olahannya) dan pemasaran markisa dari wilayah Sumatera Utara banyak mengalami kendala. Dari hasil studi Budiarta (2008) ditemukan bahwa faktor yang menyebabkan kendala dan hambatkan terhadap pengembangan bisnis markisa tersebut adalah faktor ekstern, yaitu belum terbangun secara optimal suatu kemitraan antar pelaku agribisnis pada komoditas tersebut. Sedangkan beberapa permasalahan yang dihadapi dari faktor intern petani antara lain ketidakmampuan mengatasi hama penyakit yang mengakibatkan pohon buah markisa dibiarkan mati begitu saja. Hal ini menunjukkan bahwa petani markisa tidak memiliki pengetahuan yang cukup dalam pengelolaan. Selain itu, tidak adanya bibit unggul yang disiapkan oleh petani secara individual maupun oleh kelompok tani bahkan juga dari Dinas Pertanian dan Hortikultura. Bibit pohon markisa dicari oleh petani di hutan yang tumbuh secara liar.
Beberapa permasalahan tersebut menunjukkan bahwa budidaya markisa tidak dilakukan secara profesional.

Pemberdayaan masyarakat melalui kelompok petani markisa dalam membangun pola kemitraan menjadi satu kebutuhan yang urgen. Meskipun sebenarnya pemberdayaan masyarakat pada petani markisa sudah dilakukan namun masih sebatas pada upaya pemberdayaan untuk menghadirkan modal keuangan, modal sumberdaya manusia dan modal alam. Beberapa variabel tersebut dipercaya dapat mendongkrak produktivitas dan mengabaikan variabel modal sosial yang sebenarnya sangat berperan secara ekonomi untuk meningkatkan produktivitas usaha dan efisiensi. Banyak kajain penelitian yang sudah dilakukan tentang indikator factorfaktor pemberdayaan kelompok petani (Langerodi, 2013), Davila-Aguina Et.al (2014) Dalam pelaksanaan pemberdayaan masyarakat (ekonominya) di banyak negara termasuk di Indonesia terlalu menekankan pentingnya peranan modal alam (natural capital) dan modal ekonomi (economic capital) modern seperti barang-barang modal buatan manusia, teknologi dan manajemen, dan sering mengabaikan pentingnya modal sosial seperti kelembagaan lokal, kearifan lokal, normanorma dan kebiasaan lokal.

Kemitraan yang dibangun oleh kelompok tani dapat saja dilakukan bila kelompok petani secara bersama-sama membangun kemitraan dengan sektor pengolah markisa yang dihasilkan oleh para petani. Secara umum bila dilihat dari sisi masyarakat sebagai petani markisa, dengan berkelompok akan lebih mudah mencapai tujuan-tujuan yang diinginkan dibandingkan dengan bekerja sendiri. Sesuai pendapat Bantilan \& Padmaja (2008) bahwa kelompok merupakan wadah belajar bersama dimana masyarakat bisa saling bertukar pengalaman dan pengetahuan. Selain itu, kelompok dapat membangun solidaritas sesama petani. 
Kelompok merupakan suatu wadah bagi petani untuk berkumpul dan bekerjasama dalam mencapai tujuan. Pengembangan kelompok merupakan serangkaian proses kegiatan memberdayakan kumpulan anggota masyarakat yang mempunyai tujuan bersama.

Berdasarkan hal tersebut, dimuncul- kan pertanyaan penelitian Bagaimana pengaruh modal sosial terhadap pemberdaya-an kelompok tani markisa di Propinsi Sumatera Utara? dengan mengadopsi pendapat Hoffman, Et.al (2005), modal sosial dalam penelitian ini diukur dengan variabel kepercayaan, norma sosial dan jaringan kerja. Menjadi hal yang menarik untuk mengetahui lebih lanjut bagaimana keragaan model pemberdayaan petani, sehingga diketahui gejala dan akar masalah karena tidak dibangunnya lembaga ekonomi sebagai usaha sektor agrobisnis pada komoditas markisa. Hasil dari penelitian ini selanjutnya diharapkan dapat dijadikan dasar dan landasan dalam menyusun rancangan pembinaan dan strategi bisnis komoditas buah markisa.

\section{TINJAUAN PUSTAKA \\ Pemberdayaan Masyarakat}

Pengertian pemberdayaan menurut Nauman et al ( 2010), adalah aksi memberi orang-orang kesempatan untuk membuat keputusan dalam bekerja dengan memperluas otonomi pengambilan keputusan mereka. Sedangkan Ginige (2012) menjelaskan bahwa aktivitas pemberdayaan mencakup penyebaran informasi, pemberian penge-tahuan dan upaya peningkatan kinerja selu-ruh elemenelemen yang dibutuhkan. Ada 3 tujuan utama dalam pemberdayaan masya-rakat yaitu mengembangkan kemampuan masyarakat, mengubah perilaku masyarakat, dan mengorganisir diri masyarakat. Pemberdayaan masyarakat bukan membuat masyarakat menjadi makin tergantung pada pihak lain, karena pada dasarnya setiap apa yang dinikmati harus dihasilkan atas usaha sendiri dan selanjutnya hasilnya dapat dipertukarkan dengan pihak lain. Pemberdayaan masyarakat harus bisa merubah perilaku masyarakat tersebut.

Perilaku masyarakat yang perlu diubah tentunya perilaku yang merugikan masyarakat atau yang menghambat peningkatan kesejahteraan masyarakat, Sehingga sasaran dari pemberdayaan untuk memandirikan masyarakat dan meningkatkan kemampuan masyarakat agar dapat mengembangkan diri menuju kehidupan yang lebih baik secara terus menerus dan berkesinambungan. Oleh karenanya pem-berdayaan menyangkut perubahan bukan hanya kemampuan, melainkan juga sikap, sehingga pemberdayaan masyarakat akan membangun keyakinan atas kemampuan diri dan kemauan untuk melakukan proses akulturasi yaitu proses membuka diri untuk mengikuti perubahan-perubahan lingkungan yang menjadi tuntutan kehidupan bekerjanya.

Struktur dalam kegiatan agribisnis yang sifatnya dispersal akan memberikan dampak yang tidak kondusif terhadap penciptaan sistem agribisnis berdaya saing tinggi. Pada gilirannya hal itu tidak akan mampu merespon dinamika pasar secara efektif dan efisien. Adanya keterkaitan fungsional di antara para pelaku dalam kegiatan agribisnis yang menyebabkan tidak mampunya merespon dinamika pasar (Irawan et.al., 2001). Karenanya perlu adanya suatu upaya untuk mengatasi hal tersebut agar aktivitas distribusi hasil pertanian tidak terganggu. Dengan penataan struktur agribisnis yang mengarah kepada pembentukan unit agribisnis industrial merupakan jalan keluarnya.

$$
\text { Menurut Saptana et.al (2006) }
$$
pengembangan sistem agribisnis dalam mewujudkan pembangunan pertanian di pedesaan yang tangguh, diperlukan empat pilar penunjang, yaitu : (1) eksistensi semua 
komponen sistem agribisnis secara lengkap di pedesaan, (2) pentingnya kewirausahaan dan kemitraan usaha antar pelakuagribisnis, (3) iklim lingkungan usaha yang kondusif yang memungkinkan berkembangnya agribisnis secara efisien, dan (4) adanya gerakan secara bersama dalam memasyarakatkan agribisnis. Bertitik tolak dari empat pilar penunjang sistem agribisnis tersebut, oleh karenanya dalam rangka mengembangkan kegiatan usaha pelaku agribisnis dan peningkatan peran kelembagaan agribisnis, diperlukan kebijakan teknis yang berorientasi kepada : (1) pengembangan usaha tani melalui pola kemitraan usaha, (2) konsolidasi kelembagaan di tingkat petani, (3) pening-katan keterkaitan antara sektor pertanian dengan sektor industri dan sektor lainnya, dan (4) peningkatan kerja sama organisasi profesi dalam penumbuhan pengembangan agri-bisnis.

\section{Modal Sosial}

Pengertian modal sosial menurut Putnam (1995) adalah jaringan, norma dan kepercayaan sosial yang memfasilitasi koordinasi dan kerjasama untuk saling menguntungkan. Sedangkan Hasbullah (2006) mendefinisikan modal sosial sebagai sumberdaya yang dapat dipandang sebagai investasi untuk mendapatkan sumberdaya baru. Lebih lanjut Hasbullah menyatakan bahwa modal sosial mencakup potensi kelompok dan pola-pola hubungan antar individu dalam suatu kelompok dan antar kelompok dengan ruang perhatian pada jaringan sosial, norma dan nilai serta kepercayaan antar sesama yang lahir dari anggota kelompok dan menjadi norma kelompok. Modal sosial adalah konsep yang digunakan untuk mengukur kualitas hubungan dalam komunitas, organisasi dan masyarakat (Wibisono \& Daewanto, 2015). Pendapat lain menyebutkan bahwa modal sosial adalah modal yang dimiliki oleh masyarakat dalam pemberdayaan masyarakat (Shaoling Fu, et.al,(2018). Berzina (2011), berpendapat bahwa modal sosial merupakan kemampuan masyarakat utk melakukan asosiasi satu sama lain dan selanjutnya menjadi kekuatan bagi kehidupan ekonomi dan aspek eksistensi sosialnya..

Kesimpulannya modal sosial merupakan modal yang ada dalam diri individu ataupun masyarakat untuk berasosiasi dan bekerjasama membangun jaringan berdasarkan kepercayaan dan ditopang oleh norma dan nilai sosial guna mencapai suatu tujuan. Modal sosial menjadi dasar bagi orang yang bekerjasama untuk tujuan bersama dalam kelompok. Setiap pola hubungan yang terjadi diikat oleh kepercayaan (trust), kesaling pengertian (mutual understanding) dan nilai-nilai bersama (shared value) yang mengikat anggota kelompok untuk membuat ke-mungkinan aksi bersama dapat dilakukan secara efisien dan efektif. Modal sosial akan memungkinkan manusia bekerjasama untuk menghasilkan sesuatu yang besar.

Mengacu kepada pendapat Putnam (1995), Elemen utama modal sosial mencakup norm, trust dan network. Sedangkan Fadli (2015) menyatakan bahwa modal sosial itu dinyatakan sebagai modal produktif yang terdiri atas rasa percaya, kemampuan dalam membangun jaringan kerja serta kepatuhan-nya terhadap norma yang berlaku dalam kelompok maupun masyarakat, dimana modal tersebut memberi keuntungan untuk meng-akses modal lainnya serta memfasilitasi kerjasama intra dan antar kelompok mas-yarakat. Modal Sosial terdiri atas ketrampilan berpartisipasi (partisipatory skill) dan ka-rakter (dispositions) yang memungkinkan para individu atau kelompok untuk mencapai tujuan tertentu. Menurut Hoffman, Et.al (2005), modal sosial memiliki tiga bentuk : kepercayaan (trust), norma (norm), dan jejaring (network).

Kepercayaan merupakan suatu bentuk keinginan untuk mengambil resiko dalam hubungan sosial yang didasari perasaan yakin bahwa orang lain akan 
melakukan sesuatu seperti yang diharapkan dan akan selalu bertindak dalam suatu pola yang saling mendukung (Abdullah, 2013). Dalam pan-dangan Miftahusyaian (2015), kepercayaan adalah sikap saling mempercayai di masyarakat yang memungkinkan masyarakat tersebut bersatu dengan yang lain dan memberikan kontribusi pada peningkatan modal sosial. Kepercayaan menjadi pilar kekuatan modal sosial.

Norma sosial merupakan perangkat yang disepakati untuk mengontrol perilaku seluruh anggota dalam suatu komunitas. Norma sosial senantiasa terjadi bersamaan dengan adanya interaksi manusia di dalam kelompok. Dengan kata lain, norma sosial adalah hasil dari interaksi sosial antar anggota suatu kelompok. Karenanya norma sosial tidak akan timbul dengan sendirinya tetapi terbentuk di dalam interaksi sosial antar individu di dalam kelompok. Norma sosial juga merupakan patokan-patokan umum mengenai tingkah laku dan sikap individu anggota kelompok yang dikehendaki oleh kelompok mengenai bermacam-macam hal yang berhubungan dengan kehidupan kelompok yang melahirkan norma-norma tingkah laku dan sikap-sikap mengenai segala situasi yang dihadapi oleh anggota-anggota kelompok.

Jaringan kerja merupakan pola pertukaran dan interaksi sosial yang terus berkembang. Jaringan kerja merupakan perwujudan penting dari modal sosial, baik jaringan formal maupun informal. Jaringan mewakili kategori modal sosial struktural, jaringan dihadirkan oleh harapan bersama atas manfaat/keuntungan. Namun sebenarnya jaringan ini dapat berkelanjutan lebih karena harapan akan timbal balik (resiprositas). Adanya jaringan kerja menunjukkan bahwa modal sosial tidak dibangun hanya oleh satu individu, melainkan akan terletak pada kecenderungan yang tumbuh dalam suatu kelompok untuk bersosialisasi sebagai bagian penting dari nilai-nilai yang melekat.
Modal sosial akan kuat tergantung pada kapasitas yang ada dalam kelompok masyarakat untuk membangun sejumlah asosiasi berikut membangun jaringannya. Salah satu kunci keberhasilan membangun modal sosial terletak pula pada kemampuan sekelompok orang dalam suatu asosiasi atau perkumpulan dalam melibatkan diri dalam suatu jaringan hubungan sosial. Modal Sosial akan kuat tergantung pada kapasitas yang ada dalam kelompok masyarakat untuk membangun sejumlah asosiasi berikut membangun jaringannya.

Berdasarkan kerangka pemikiran tersebut di atas, maka hipotesis dalam penelitian ini dirumuskan sebagai berikut : Kepercayaan, norma sosial dan jaringan kerja berpengaruh terhadap pemberdayaan kelompok tani markisa Utara baik secara simultan maupun parsial.

\section{METODE PENELITIAN}

Penelitian ini dilakukan di Propinsi Sumatera Utara tepatnya pada Kabupaten di wilayah Propinsi Sumatera Utara yang menjadi basis pertanian untuk komoditas markisa. Menggunakan studi dokumentasi dari BPS tahun 2016, diketahui bahwa sentra markisa di Propinsi Sumatera Utara terdapat di Kabupaten Karo, Kabupaten Simalungan, Kabupaten Dairi dan Kabupaten Tapanuli Utara. Oleh karenanya penelitian ini dilakukan pada keempat daerah tersebut. Populasi dari penelitian ini adalah seluruh petani markisa yang berjumlah 259 (data dokunen Dinas Pertanian propinsi Sumatera Utara) yang tersebar pada 4 (empat) kabupaten, Dari setiap Kabupaten diambil dua desa yang memiliki jumlah petani markisa dengan volume produksi atau luas panen relatif stabil setiap tahunnya. Pengambilan kabupaten sebagai sampel dilakukan dengan purposive sampling, sedangkan pengambilan sampel petani markisa digunakan stratified random sampling dengan memperhatikan responden yang benar-benar dapat memberikan 
informasi data yang tepat sesuai dengan tujuan penelitian. Jumlah sampel penelitian ini sebanyak 100 orang petani.

Pengumpulan data dalam penelitian ini dilakukan melalui kuesioner, wawancara mendalam (indepth interviewer) dan Studi Dokumentasi. Dengan mengadopsi pendapat Hoffman, Et.al (2005), data berupa modal sosial dikelompokkan menjadi tiga variabel yaitu: 1. kepercayaan, 2, norma sosial dan 3. jaringan kerja. Sedangkan data tentang pemberdayaan masyarakat diukur dengan perilaku petani (Nielsen dan Christian, 2003). Teknik analisis data yang digunakan antara lain statistik deskriptif dan statistik inferensial. Uji hipotesis menggunakan $\mathrm{F}$ test dan $\mathrm{t}$ test.

\section{HASIL}

DAN

\section{PEMBAHASAN}

\section{Deskripsi Data Penelitian}

Tahap awal penelitian dilakukan dengan uji coba instrumen pada sampel sebanyak 30 orang responden. Hasil uji validitas instrumen menggunakan korelasi product moment diketahui bahwa terdapat 1 butir tidak valid dan 20 butir dinyatakann valid untuk variabel perilaku petani. Untuk variabel kepercayaan, diperoleh 2 butir tidak valid dan 18 butir dinyatakan valid sedangkan untuk variabel norma sosial, seluruh butir sebanyak 18 dinyatakan valid sementara untuk variabel jaringan kerja dari 20 butir, 3 butir dinyatakan tidak valid dan 17 butir dinyatakan valid. Uji reliabillitas instrumen menggunakan cronbach alpha. Semua butir kuesioner yang tidak valid tidak digunakan dalam pengumpulan data penelitian. Hasil uji reliabilitas instrumen beserta data deskriptif penelitian yang dikumpulkan ditunjukkan pada Tabel $1 \mathrm{di}$ bawah ini.
Tabel.t

Hasil Uj Reliabilstas dan Analisis Desknptif

\begin{tabular}{|c|c|c|c|c|}
\hline & $\begin{array}{l}\text { Perilako } \\
\text { Petra: }\end{array}$ & $\begin{array}{l}\text { Keper- } \\
\text { cryan }\end{array}$ & $\begin{array}{l}\text { Nonata } \\
\text { Sosial }\end{array}$ & $\begin{array}{l}\text { Janizan } \\
\text { verja }\end{array}$ \\
\hline Retiabilitas & 0,917 & 0.916 & 0,377 & 0,793 \\
\hline Meza Ideal & 70,500 & 60500 & 65,000 & 67,000 \\
\hline St Deriza Ideal & 4,850 & 6,500 & 4,300 & 3,660 \\
\hline \multicolumn{5}{|l|}{ Kategon } \\
\hline Tingsi & 23 & $3 \mathrm{I}$ & 29 & 27 \\
\hline Sedang & 64 & 43 & 53 & 56 \\
\hline Rendet & 13 & 26 & 18 & 17 \\
\hline
\end{tabular}

Samber : Dast Pentitian yout Diolah

\section{Analisis Data dan Uji Hipotesis}

Model regresi ganda dengan variabel dependen (Y) perilaku petani dan variabel independen kepercayaan $\left(\mathrm{X}_{1}\right)$,

norma sosial $\left(\mathrm{X}_{2}\right)$ dan jaringan kerja $\left(\mathrm{X}_{3}\right)$ adalah sebagai berikut : $\hat{Y}=a+b_{1} X_{1}+b_{2} X_{2}$ $+b_{3} X_{3}$. Berdasarkan pada tabel 2 tersebut di atas maka model yang terbentuk dari hasil regresi adalah sebagai berikut: $\mathrm{Y}=27,552+$ $0,224 X_{1}+0,188 X_{2}+0,263 X_{3}+e$.

Tabel. 2

Hasil Analisis Regresi terhadap Perilaku Petani

\begin{tabular}{|l|c|c|c|}
\hline \multicolumn{1}{|c|}{ Varabel } & $\begin{array}{c}\text { Unstaofardized } \\
\text { Coefficients }\end{array}$ & t test & Sig \\
\hline Constants & 27.552 & 3,129 & 0,002 \\
\hline Repercayaan & 0,224 & 4,536 & 0,000 \\
\hline Norma sosial & 0,183 & 2,343 & 0,021 \\
\hline Jaringan Kerja & 0,263 & 2,536 & 0,013 \\
\hline Ftest & 12.581 & & \\
\hline Sig & .000 & & \\
\hline R Square & .282 & & \\
\hline
\end{tabular}

Sumber : Data Peselitian yang Diolah

Berdasarkan hasil analisis statistikF test seperti terdapat pada tabel 2. Diketahui bahwa nilau F hutung sebesar 12,581 dengan signifikansi 0,000 berada di bawah signifikansi 0,05 . Hasil tersebut mennguatkan bahwa hiporesis penelitian yang menyatakan bahwa kepercayaan, norma sosial dan jaringan kerja berpengaruh secara bersama $=$ sama terhadap pemberdayaan kelompok tani markisa Utara diterima. 0,000. Dengan demikian kepercayaan, norma sosial dan jaringan kerja memiliki pengaruh yang signifikan terhadap perilaku petani markisa. Selain itu dengan melihat

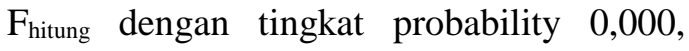
maka dapat ditarik kesimpulan bahwa model regresi dapat dipakai untuk memprediksi perilaku petani markisa di propinsi Sumatera Utara. 
Uji t (uji parsial) dilakukan untuk melihat secara individu pengaruh dari variabel independent yaitu: variabel $\mathrm{X} 1, \mathrm{X} 2$, $\mathrm{X}_{3}$ terhadap variabel dependent (Y). Hasil uji t yang diperoleh dari dari analisis data seperti diringkas pada tabel 2 di atas.

Hasil uji t pada $X_{1}$ yaitu 4,536, dengan signifikansi 0,000 Berdasarkan hasil tersebut maka hipotesis yang menyatakan bahwa kepercayaan berpengaruh terhadap perilaku petani markisa di Propinsi Sumatera Utara diterima. Sedangkan pada variabelX2 hasil uji t sebesar 2,343 dengan signifikansi 0,021 hasil tersebut membuktikan bahwa norma sosial berpengaruh terhadap perilaku petani markisa di Propinsi Sumatera Utara. Demikian juga hasil uji t untuk $\mathrm{X}_{3}$ sebesar 2,536 dengan signifikansi 0,013 , hasil ini juga membuktikan bahwa jaringan kerja berpengaruh terhadap perilaku petani markisa di Propinsi Sumatera Utara.

Koefisien determinasi digunakan untuk melihat kemampuan model dalam menjelaskan variabel independen terhadap variabel dependen dari model yang dibangun. Berdasarkan hasil pengujian statistik untuk model dengan variabel independen kepercayaan, norma sosial dan jaringan kerja serta variabel dependen perilaku usaha diperoleh nilai koefisien determinasi dengan nilai $R$ Square sebesar 0.282 berarti variabel modal sosial mampu menjelaskan variasi variabel perilaku petani sebesar $28,2 \%$, sisanya sebesar $71,8 \%$ diterangkan oleh variabel lain.

\section{Pembahasan Hasil Penelitian}

Perkembangan produk dan produksi pertanian buah markisa menunjukkan bahwa setiap minggunya rata-rata mencapai 20,901 ton. Data ini menunjukkan peningkatan dibandingkan beberapa tahun sebelumnya. Namun bila dibandingkan dengan kebutuhan produksi olahan buah markisa ternyata jumlah tersebut masih belum dapat memenuhi kebutuhan buah markisa sebagai bahan baku perusahaan. Hasil studi di lapangan menunjukkan bahwa pasokan buah markisa dari petani markisa di Sumatera Utara masih sangat kurang, setiap minggunya tidak lebih dari 50 ton sementara kebutuhan bisa mencapai 120 ton per minggu, sehingga terkadang kontinuitas produksi sangat terganggu.

Meskipun pangsa pasar buah markisa jelas dan sangat besar peluangnya namun terdapat beberapa hal yang menyebabkan turunnya produktivitas petani markisa. Hasil penelitian di lapangan mengindikasikan bahwa minat petani untuk lebih membudidayakan buah markisa makin menurun dan tetap saja rendah. Hal ini disebabkan oleh berbagai permasalahan yang dihadapi petani dalam mengelola pertanian. Rendahnya minat petani tersebut menunjukkan bahwa permasalahan yang dihadapi petani diselesaikan secara individual karenanya perlu adanya program kemitraan petani melalui pemberdayaan kelompok tani. Setelah kelompok tani dibangun selanjutnya dipacu dengan mengintrodusir modal sosial dalam kelompok tani tersebut agar berbagai permasalahan yang dihadapi dapat segera diselesaikan.

Berdasarkan hasil penelitian, modal sosial yang diukur dengan kepercayaan, norma sosial dan jaringan kerja berpengaruh terhadap perilaku petani markisa di Propinsi Sumatera Utara. Hasil pengujian statistik menunjukkan bahwa variabel kepercayaan, norma sosial dan jaringan kerja secara simultan dan parsial berpengaruh positifdan signifikan terhadap perilaku usaha. Model yang terbentuk dari hasil regresi adalah sebagai berikut: $\mathrm{Y}=27,552+0,224 \mathrm{X}_{1}+$ $0,188 \mathrm{X}_{2}+0,263 \mathrm{X}_{3}+\mathrm{e}$, artinya meningkatnya perlakuan terhadap kepercayaan, norma sosial dan jaringan kerja akan menyebabkan kenaikan perilaku petani, begitu juga sebaliknya. 


\section{Pengaruh Kepercayaan terhadap Perilaku Petani}

Hasil pengujian membuktikan bahwa kepercayaan berpengaruh terhadap perilaku usaha. Hal ini dapat diketahui dari nilai $t_{\text {hitung }}=4,536$ dengan signifikansi menyelesaikan masalah juga akan semakin tinggi. Bila dikaitkan dengan permasalahan petani yang ditemukan di lapangan, misalnya kesulitan untuk mendapatkan bibit markisa. Preferensi dari petani bahwa Dinas Pertanian dan Hortikultura yang terkait dengan pengelolaan ini ikut bertanggung jawab terhadap penyelesaian permasalahan yang dihadapi petani. selain itu, kepercayaan petani juga didasari keyakinan bahwa untuk mengatasi hama penyakit markisa, petani akan dibantu melalui penyuluhan dari PPL Dinas Pertanian dan Hortikultura setempat. Hasil penelitian ini sejalan dengan pendapat Dewi (2011) dan Rangkuty (2018) yang menyatakan bahwa aktivitas yang di dasari atas keyakinan dan rasa saling mempercayai yang tinggi akan meningkatkan perilaku masyarakat dalam berbagai ragam bentuk dan dimensi. Dengan demikian kepercayaan dan bentuk keyakinan dan rasa saling mempercayai akan menumbuhkan motivasi untuk berperilaku menuju kemandirian. sebesar 0,000 lebih kecil dari 0,05.

Kepercayaan dalam penelitian ini diukur dengan kesediaan petani untuk mengambil resiko berdasarkan keyakinan dan harapan bahwa orang lain akan memberikan bantuan penyelesaian atas permasalahan yang dihadapinya.

Dalam konteks ini, preferensipetani atas kepercayaan yang dibangun adalah semakin tinggi kepercayaan maka intensitas petani untuk merubah perilaku usaha dalam

\section{Pengaruh Norma Sosial terhadap Perilaku Petani}

Hasil pengujian $\mathrm{t}$ test membuktikan bahwa norma sosial berpengaruh terhadap perilaku petani. Nilai uji t menunjukkan nilai sebesar 2,343 dengan signifikansi sebesar 0,021 lebih kecil dari $\alpha=0,05$. Norma sosial dalam penelitian ini diukur dengan kepatuhan dari petani terhadap aturan-aturan yang mengatur bagaimana individu seharusnya dan sebaiknya berperilaku. Norma sosial dalam penelitian lebih ditekankan pada konformitas, yaitu perilaku yang mengikuti suatu kelompok yang didorong oleh keinginan individu itu sendiri. Hasil penelitian ini menunjukkan bahwa norma sosial digunakan oleh petani dalam kelompok dengan harapan dapat mengurangi permasalahan dan ketidak- pastian karena faktor lingkungan. Melalui pemberdayaan dalam kelompok tani, akan terjalin hubungan baik diantara mereka dalam ikatan organisasi ekonomi kelompok tani. Kuatnya modal sosial yang ditunjukkan dengan kepatuhan terhadap norma sosial akan membangun nilai kebersamaan diantara petani terutama kebersamaan dalam menyelesaikan permasalahan pengelolaan lahan pertanian markisa. Dalam konteks ini norma sosial akan membangun keterikatan internal yang mewarnai struktur kolektif dan memberikan kohesifitas dan keuntungankeuntungan bersama dari proses dinamika yang dibangun oleh para petani markisa dalam kelompok tani.

Beberapa indikator yang digunakan sebagai alat pengukuran norma sosial antara lain: sikap partisipatif, sikap saling memperhatikan, saling memberi dan menerima, saling percaya mempercayai dengan diperkuat oleh nilai-nilai dan normanorma yang mendukungnya. Selain itu, kemauan masyarakat untuk secara terus menerus proaktif baik dalam mempertahankan nilai, membentuk jaringan kerjasama maupun dengan penciptaan kreasi dan ideide baru. Potensi pengembangan usaha melalui perubahan perilaku terutama dalam mematuhi norma-norma tersebut pada akhirnya akan membentuk petani markisa yang mandiri. 


\section{Pengaruh Jaringan Kerja terhadap Perilaku Usaha}

Pengujian jaringan kera terhadap perilaku petani menggunakan uji t. Hasil analisis statistik menggunakan uji $\mathrm{t}$ untuk mengetahui pengaruh jaringan kerja terhadap perilaku prtani adalah sebesar 2,536 dengan nilai signifikansi sebesar 0,013 lebih kecildari

$\alpha=0,05$. Dari hasil tersebut dapat disimpullkan bahwa jaringan kerja berpengaruh terhadap perilaku petani. Dalam penelitian ini, jaringan kerja diukur dengan hubungan sosial yang diikat oleh kepemilikan informasi, rasa percaya dan saling memahami dan kesamaan nilai dan saling mendukung. Berdasarkan hasil penelitian ini, bagi petani jaringan kerja akan memfasilitasi terjadinya komunikasi dan interaksi, memungkinkan tumbuhnya kepercayaan dan memperkuat kerjasama. Jaringan kerja yang erat akan memperkuat perasaan kerjasama masyarakat yang terlibat serta manfaat-manfaat dari partisipasinya itu.

\section{KESIMPULAN DAN SARAN}

Berdasarkan analisis data yang dilakukan dan hasil penelitian yang sudah dipaparkan, maka beberapa kesimpulan dari penelitian ini adalah sebagai berikut : Sesuai dengan model penelitian, modal sosial yang diukur dengan kepercayaan, norma sosial dan jaringan kerja berpengaruh signifikan terhadap perilaku petani. Kepercayaan mempunyai pengaruh signifikan terhadap perilaku petani. Norma sosial mempunyai pengaruh signifikan terhadap perilaku petani. Jaringan kerja mempunyai pengaruh signifikan terhadap perilaku petani. Variabel kepercayaan, norma sosial dan jaringan kerja mempengaruhi perilaku petani

\section{REFERENSI}

Abdullah, Suparman. 2013. Potensi dan
Suatu Komunitas. SOCIUS Vol. Mei XII - Januari

Berzina, Kristine. 2011. Entrepeise Related Social Capital : Dofferent Levels Pf Social Capital Accumulation. Economics \& Sociology, Vol. 4, No 2

Budiarta, Kustoro. dkk. 2008. Pengembangan Model Kelembagaan Mitra Usaha Sektor Agribisnis Pada Komoditas Markisa di Propinsi Sumatera Utara. Laporan Penelitian Hibah Bersaing, DP2M-Dikti Jakarta

Davila-Aguirre, M.C., Hanley, L.M., Lozano- Fernandez, G., \& Lyons, T.S. (2014). Leveraging low income farmers'performance through empowerment: Analysis of a sustainable initiative in Mexico. Management \& Marketing. Challenges for the Knowledge Society, 9(2), 175. 192.1

Dewi, Komala, Ratna. 2011. Modal sosial Subak Sebagai Energi Sosial dalam Pembangunan Pertanian di Perkotaan : Kasus Subak Kerdung Kota Denpasar Jurnal dwijenAGRO Vol. 2 No. 1 I tahun.

Fadli. 2015. Modal Sosial Dan Pendapatan Masyarakat Social Capital And Community Income. Jurnal Agrium 12(1), Maret/

Ginige, Tamara \& Richards, Deborah/ 2012. A Model for Enhancing Empowerment in Farmers using Mobile Based Information System.. 23rd Australasian Conference on Information Systems. 3-5 Dec 2012, Geelong

Hoffman, James, J. Hoelscher, Mark, L.and Sherif, Karma. 2005. Social Capital, Knowledge Management, and Sustained Superior Performance. Journal of Knowledge Management Vol 9 (3) , pp $93-100$

\section{Kekuata Modal Sosial dalam}


Irawan, B. R. Nurmanaf, E.L. Hastuit. C. Muslim, Y. Supriyatna dan V.Darwis. 2001. Studi Kebijaksanaan Pengembangan Agribisnis Komoditas Unggulan Hortikultura. Pusat Penelitian dan Pengembangan Sosial Ekonomi Pertanian, Badan Penelitian dan Pengembangan Pertanian, Departemen Pertanian, Bogor.

Langerodi, M.C. 2013. Farmers' empowerment indicators modeling in Mazandaran province, Iran. International Journal of Agricultural and Crop Sciences, 5(7), 769-776

Miftahusyaian, Mohammad. 2015. Kapital Sosial dan Pembangunan di Indonesia. J-PIPS (Jurnal Pendidikan Ilmu Pengetahuan Sosial) VOL 2, NO 1. Fakultas Ilmu Tarbiyah dan Keguruan Universitas Islam Negeri UIN Maulana Malik Ibrahim Malang

Nauman, Shazia. Et.al. 2010. Pattern of Empowerment and Leadership Style in Project Environment. International Journal of project Management. Volume 28 Issue 7 ,

November 2010.

Nielson, John, Flohr and Christian, Preuthun, Pedersen. 2003. The Consequencesand limits of Empowerment in Financial Services. Scondinavian Journal of Management 19.63-83

Putnam, Robert. 1995. “Tuning In, Tuning Out : The Strange Disappearance of Social Capital in America". Political Studies Vol. 4 No. 28.

Rangkuty, Putra, Rakhmadsyah. 2018. Modal Sosial dan Pemberdayaan Perempuan (Kajian Modal Sosial dalam Pemberdayaan Perempuan Melalui Kegiatan PNPM Mandiri
Pedesaan). Unimal Press. Lhokseumawe

Shaoling Fu 1, Hua Liu 1, Kim Hua Tan , Yuanzhu Zhan, Yalan Ding and Wene Qi. 2018. How Social Capital Affects the Quality Performance of Agricultural Products: Evidence from a Binary Perspective of China. Sustainability. 10, 3009

Wibisono, Annas, Mukti, Galih \& Darwanto. 2016. Strategy of Strengthening Social Capital of Farmer Group in Agricultural Development. jEJAK Journal of Economics and Policy. Vol $9(1)$ 